\title{
Detection and quantification of S-100 protein in ocular tissues and fluids from patients with intraocular melanoma
}

\author{
ALISTAIR J COCHRAN, ${ }^{23}$ GARY N HOLLAND, ${ }^{46}$ ROMAINE E SAXTON, ${ }^{28}$ \\ BERTIL E DAMATO, 9 WALLACE R FOULDS, ${ }^{9}$ HARVEY R HERSCHMAN, ${ }^{5}$ \\ ROBERT Y FOOS, ${ }^{36}$ BRADLEY R STRAATSMA, ${ }^{46}$ AND WILLIAM R LEE \\ From the 'Armand Hammer Laboratories, Division of Surgical Oncology, Jonsson Comprehensive Cancer

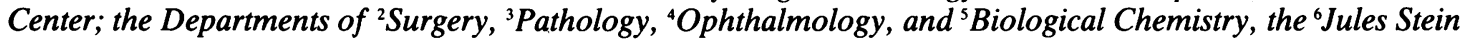 \\ Eye Institute, and the ${ }^{7}$ Laboratory of Biomedical and Environmental Sciences, UCLA School of Medicine, Los \\ Angeles CA 90024; the ${ }^{8}$ Surgical Service, Veterans Administration Medical Center, Sepulveda, CA, 91343; and \\ the ${ }^{9}$ Tennent Institute of Ophthalmology, Western Infirmary, Glasgow G11 6NT, Scotland
}

SUMMARY S-100 protein is a 21000 dalton acidic calcium-binding protein present in ocular melanomas and some normal ocular tissues. Ocular fluids and extracts of ocular tumours were examined by a sensitive radioimmunoassay that could detect less than $5 \mathrm{ng}$ of S-100 protein in minute volumes of fluid. Three ocular melanoma biopsy specimens had S-100 protein at levels between 25 and $1300 \mathrm{ng} / \mathrm{ml}$, comparable to that found in a cutaneous melanoma biopsy specimen $(1000 \mathrm{ng} / \mathrm{ml})$. (SI conversion: $\mathrm{ng} / \mathrm{ml}=\mu \mathrm{g} / \mathrm{l}$.) Six melanoma culture lines had 1000 to $125000 \mathrm{ng} / \mathrm{ml}$. Four lymphoblastoid cultures had less than $2 \mathrm{ng} / \mathrm{ml}$, and three colon carcinoma cultures had 180 $\mathrm{ng} / \mathrm{ml}$. Subretinal fluid from 23 melanoma-containing eyes had 10 to $76800 \mathrm{ng} / \mathrm{ml}$. Lesser amounts were found in eyes with small, anteriorly located, lightly pigmented tumours. Vitreous from 3 melanoma-containing eyes had 10000 to $11000 \mathrm{ng} / \mathrm{ml}$. Vitreous obtained from three eyes during tractional retinal detachment repair had 500 to $1600 \mathrm{ng} / \mathrm{ml}$, and vitreous obtained at necropsy from six normal eyes had 2 to $120 \mathrm{ng} / \mathrm{ml}$. Aqueous from six melanoma-containing eyes had 10 to 30 $\mathrm{ng} / \mathrm{ml}$, levels not significantly different from those observed in three normal eyes $(80-120 \mathrm{ng} / \mathrm{ml})$. This approach provides new insight into the interaction of ocular tumours and adjacent ocular fluids and may, with more specific tumour markers, have diagnostic applications.

Early and accurate diagnosis offer cancer patients the best chance of survival. In ocular melanoma, ophthalmoscopy and supplementary techniques such as fluorescein angiography, ultrasonography, or ${ }^{32} \mathrm{P}$ uptake permit an accurate diagnosis to be made in most patients. ${ }^{1}$ In occasional patients, however, conditions such as a rhegmatogenous retinal detachment with associated subretinal blood, nonneoplastic exudative detachment, or tumours metastatic to the choroid may be difficult to differentiate from a primary intraocular melanoma.

To differentiate patients with intraocular melanoma from those with non-melanomatous tumours or conditions simulating ocular tumours

Correspondence to Alistair J Cochran, MD, UCLA Medical Center, Los Angeles, CA 90024 , USA. attempts have been made to find evidence of tumourrelated immune reactivity. ${ }^{23}$ Although immunological reactions are of some value in separating groups of ocular melanoma patients from those without melanoma, they are insufficiently discriminatory when applied to the individual patient.

As a possible alternative diagnostic approach the detection of a melanoma product or melanoma cell constituent in the vitreous or aqueous fluids was considered. S-100 protein is a marker that is universally present in abundant quantities in cutaneous malignant melanoma, though not specific for this tumour. The authors have recently demonstrated the presence of S-100 protein in ocular melanomas. ${ }^{4}$ S-100 protein was therefore sought in fluids from eyes with intraocular melanoma or other, non- 
melanomatous disease processes. A study of S-100 protein distribution within the eye could also provide valuable information on the basic biology of intraocular tumours and the extent to which tumourderived molecules permeate the eye. The availability of a sensitive radioimmunoassay made it possible to detect nanogram quantities of S-100 protein with great precision in minute samples.

\section{Materials and methods}

The quantity of S-100 protein was determined in tissues from three ocular melanomas, one cutaneous melanoma, one ocular glioma, and normal brain and sclera. Twenty-three subretinal fluid samples, 22 vitreous samples, and nine aqueous humour samples were also examined. Fluids from patients who had undergone cataract extraction and from corneal donors served as controls. Tumour tissues and ocular fluids were contributed by members of the Tennent Institute of Ophthalmology, Glasgow, Scotland, and the Jules Stein Eye Institute, Los Angeles, CA. Melanoma tissue and fluids were obtained during tumour resection (Tennent Institute) or immediately after enucleation. The Tennent Institute samples were transported to UCLA in a frozen state, and all samples were stored at $-70^{\circ} \mathrm{C}$. All diagnoses were established clinically and confirmed histologically where appropriate. Tissue culture cell lines (six melanomas, four lymphoblastoid, and three colon carcinomas) were obtained from the tissue culture collection, Division of Surgical Oncology, UCLA. All samples were coded, and diagnoses were not available to individuals performing radioimmunoassays until the S-100 protein content had been recorded.

RADIOIMMUNOASSAY FOR S- 100 PROTEIN

Tissue specimens were weighed to determine $50 \%$ weight/volume, minced finely with scissors, and resuspended in lysis buffer $(0.5 \% \mathrm{NP} 40,150 \mathrm{mM}$ $\mathrm{NaCl}, 10 \mathrm{mM} \mathrm{Na}_{2}, \mathrm{HPO}_{4}, \mathrm{pH} \mathrm{7.4)}$ ) for 30 minutes. Tissue debris was removed by pelleting for 5 minutes at $13000 \mathrm{~g}$ in microfuge tubes. Samples of eye fluids and pelleted tissue culture lines were solubilised by mixing with an equal volume of lysis buffer at $4^{\circ} \mathrm{C}$ for 30 minutes.

The radioimmunoassay was performed on dilutions of each solubilised test sample in duplicate microfuge tubes containing $100 \mu$ l RIA buffer $(150$ $\mathrm{mM} \mathrm{NaCl}, 0.5 \mathrm{mM} \mathrm{MgSO} 4,0 \cdot 15 \mathrm{mM} \mathrm{CaCl}_{2}, 0 \cdot 1 \%$ bovine serum albumin, and $10 \mathrm{mM}$ trometamol (TRIS), pH 7.4). Control samples containing serial doubling dilutions of bovine brain S- 100 protein (range $1-500 \mathrm{ng} / \mathrm{ml}$ ) were included in separate duplicate tubes for each assay. Radiotracer at $5 \times 10^{+}$ $\mathrm{cpm} / 50 \mu \mathrm{l}\left(10 \mathrm{ng}{ }^{125} \mathrm{I}-\mathrm{S}-100\right.$ protein, $\left.5 \times 10^{\mathrm{h}} \mathrm{cpm} / \mu \mathrm{g}\right)$ was added to each tube, followed by $50 \mu \mathrm{l}$ of rabbit anti-S-100 protein serum (1:64000 final dilution). After incubation at $4: \mathrm{C}$ for 18 hours, immune complexes were isolated by adding $25 \mu \mathrm{l}$ of $10 \% \mathrm{w} / \mathrm{v}$ prewashed Straphylococcus aureus (Pansorbin, Calbiochem) for 1 hour at $4^{\circ} \mathrm{C}$. Bound radioactivity was determined in a gamma spectrometer after repeated washing and pelleting of bacteria at $13000 \mathrm{~g}$ in a microfuge. S-100 protein antigen concentration in test samples was calculated from the midpoint of the standard S-100 protein competitive binding curve included with each assay. Maximum S-100 protein radiotracer binding of $10^{4} \mathrm{cpm}$ and minimum binding of $300 \mathrm{cpm}$ allowed detection of less than $5 \mathrm{ng}$ of S-100 proteon. (SI conversion: $n g / m l=\mu g / l)$.

\section{Results}

Table 1 lists the S-100 protein content of intraocular tumours and normal tissues. Two of three primary intraocular melanomas contained substantial S-100 protein (1300 and $1200 \mathrm{ng} / \mathrm{ml}$ of tumour extract), while a third contained little S- 100 protein $(25 \mathrm{ng} / \mathrm{ml})$. There was no apparent correlation between S-100 protein content and tumour size or cytology. The tumour that contained little S-100 protein was the most heavily pigmented. Substantial levels of S-100 protein were present in extracts of a biopsy sample of cutaneous melanoma that had metastasised to the inguinal lymph nodes $(1000 \mathrm{ng} / \mathrm{ml})$, a low-grade retinal peripapillary astrocytoma of mixed morphological pattern $(480 \mathrm{ng} / \mathrm{ml})$, and normal brain tissue obtained at necropsy $(2500 \mathrm{ng} / \mathrm{ml})$. Normal sclera contained little S-100 protein $(<25 \mathrm{ng} / \mathrm{ml}$ of extract). (SI conversion: $n g / m l=\mu g / l$.)

Table 2 lists the S-100 protein content of a number of tissue culture cell lines. Extracts of six melanoma derived cell lines contained substantial but varied

Table $1 S$-100 protein content of tumour biopsies and normal tissues

\begin{tabular}{|c|c|c|c|c|c|}
\hline \multirow[t]{2}{*}{$\begin{array}{l}\text { Tumour } \\
\text { classification }\end{array}$} & \multirow{2}{*}{$\begin{array}{l}S-100 \\
\text { protein } \\
(n g / m l)\end{array}$} & \multicolumn{4}{|c|}{$\begin{array}{l}\text { Ocular melanoma tumour } \\
\text { characteristics }\end{array}$} \\
\hline & & Site & $\begin{array}{l}\text { Volum } \\
\left(\mathrm{mm}^{3}\right)\end{array}$ & Cytology & Pigment \\
\hline Ocular melanoma case 1 & 1300 & \multirow{3}{*}{\multicolumn{2}{|c|}{$\begin{array}{l}\text { Choroid } 1515 \\
\text { Choroid } 840 \\
\text { Choroid } 1870\end{array}$}} & Mixed & Light \\
\hline Ocular melanoma case 2 & 1200 & & & Spindle & Light \\
\hline Ocular melanoma case 3 & 325 & & & Mixed & Heavy \\
\hline Cutaneous melanoma* & 1000 & & & & \\
\hline Ocular glioma & 480 & & & & \\
\hline Normal brain & 2500 & & & & \\
\hline Normal sclera & $<25$ & & & & \\
\hline
\end{tabular}

* Metastatic deposit in inguinal lymph node. SI conversion: $\mathrm{ng} / \mathrm{ml}=\mu \mathrm{g} / \mathrm{l}$. 
Table 2 S-100 protein content of cultured cell lines

\begin{tabular}{llcl}
\hline Cell line & Cell type & $\begin{array}{l}\text { S-100 protein } \\
(\mathrm{ng} / \mathrm{ml})\end{array}$ & Melanin content \\
\hline M20* & Melanoma & 125000 & Light \\
M21 & Melanoma & 80000 & Light \\
M1q & Melanoma & 80000 & Light \\
M32 & Melanoma & 25600 & Light \\
M926 & Melanoma & 12800 & Light \\
M12 & Melanoma & 1000 & Heavy \\
L20* & Lymphoblastoid & $<2$ & None \\
LDOn & Lymphoblastoid & $<2$ & None \\
L14 & Lymphoblastoid & $<2$ & None \\
PL3 & Lymphoblastoid & $<2$ & None \\
DONCA & Colon carcinoma & 180 & None \\
HT29 & Colon carcinoma & 180 & None \\
SW116 & Colon carcinoma & 180 & None \\
\hline
\end{tabular}

*M20 and L20 are paired cultures derived from the same patient. SI conversion: $\mathrm{ng} / \mathrm{ml}=\mu \mathrm{g} / \mathrm{l}$.

amounts of S-100 protein $(1000-125000 \mathrm{ng} / \mathrm{ml})$. Four lymphoblastoid cell lines, produced by Epstein-Barr virus transformation of peripheral blood lymphocytes, contained virtually no S-100 protein. Among them was a lymphoblastoid cell line (L20) that was autologous to a melanoma cell line (M20) that contained $125000 \mathrm{ng} / \mathrm{ml}$ of S-100 protein. Three

Table 3 S-100 protein content of subretinal fluid from patients with ocular melanoma

\begin{tabular}{|c|c|c|c|c|c|}
\hline \multirow{2}{*}{\multicolumn{2}{|c|}{$\begin{array}{r}\text { Patient } S-100 \\
\text { protein } \\
(n g / m l)\end{array}$}} & \multicolumn{4}{|c|}{ Ocular melanoma tumour characteristics } \\
\hline & & Site & $\begin{array}{l}\text { Volume } \\
\left(\mathrm{mm}^{3}\right)\end{array}$ & Cytology & Pigmentation \\
\hline 1 & 76800 & Choroid & 1632 & Mixed & Light \\
\hline 2 & 64000 & Choroid & 2475 & Mixed & Moderate \\
\hline 3 & 2200 & Angle/CB* & 972 & Mixed & Moderate \\
\hline 4 & 160 & $\begin{array}{l}\text { Choroid } \\
\text { (anterior) }\end{array}$ & 540 & $\begin{array}{l}\text { Mixed/ } \\
\text { inflammatory }\end{array}$ & Light \\
\hline 5 & 80 & $\mathrm{CB}$ & 470 & $\begin{array}{l}\text { Mixed/ } \\
\text { inflammatory }\end{array}$ & Heavy \\
\hline 6 & 32000 & Choroid & 3168 & Mixed & Heavy \\
\hline 7 & 14000 & $\mathrm{CB} /$ choroid & 2720 & Mixed & Light \\
\hline 8 & 32000 & Choroid & 258 & Spindle & Light \\
\hline 9 & 18000 & Choroid & 117 & Spindle & Light \\
\hline 10 & 12500 & Choroid & 450 & Spindle & Light \\
\hline 11 & 12000 & $\mathrm{CB} /$ choroid & 1512 & Spindle & Light \\
\hline 12 & 2176 & CB/choroid & 960 & Mixed & Patchy/heavy \\
\hline 13 & 896 & Choroid & 2025 & Mixed & Light \\
\hline 14 & $<10$ & $\mathrm{CB}$ & 243 & Mixed & Heavy \\
\hline 15 & 15000 & Choroid & 840 & Mixed & Moderate \\
\hline 16 & 2048 & Choroid & 594 & Spindle & Moderate \\
\hline 17 & 640 & Choroid & 960 & Spindle & Heavy \\
\hline 18 & 768 & Choroid & 2535 & Mixed & Patchy \\
\hline 19 & 50 & $\begin{array}{l}\text { Choroid } \\
\text { (anterior) }\end{array}$ & 1188 & Mixed & Patchy \\
\hline 20 & 16 & Choroid & 2880 & Mixed & Very heavy \\
\hline 21 & 8192 & Choroid & 2016 & Spindle & Light \\
\hline 22 & 8192 & Choroid & 3042 & Mixed & Moderate \\
\hline 23 & 3000 & Choroid & 1904 & Mixed & Moderate \\
\hline
\end{tabular}

${ }^{*} \mathrm{CB}=$ ciliary body.

SI conversion: $\mathrm{ng} / \mathrm{ml}=\mu \mathrm{g} / \mathrm{l}$. colon cancer lines had relatively small amounts of $\mathrm{S}-100$ protein $(180 \mathrm{ng} / \mathrm{ml})$.

Table 3 lists S-100 protein content of subretinal fluid from eyes containing melanomas. The S-100 protein content of fluids varied from negligible $(<10$ $\mathrm{ng} / \mathrm{ml})$ to very high $(76800 \mathrm{ng} / \mathrm{ml})$. Subretinal fluids that contained substantial $(>1000 \mathrm{ng} / \mathrm{ml}) \mathrm{S}-100$ protein were usually from patients with light to moderately pigmented tumours (13 of 15). Many were composed primarily of spindle type cells ( 6 of 15). By contrast, subretinal fluids that contained little $\mathrm{S}-100$ protein came from patients with tumours of mixed cytology ( 7 of 8$)$ and tumours with substantial pigmentation (6 of 8 ). Four of 8 tumours that contained $<1000 \mathrm{ng} / \mathrm{ml} \mathrm{S}-100$ protein were located in the anterior part of the eye, including two ciliary body tumours. By contrast only 4 of 15 tumours located more posteriorly were low in S-100 protein.

Table 4 lists S- 100 protein content of vitreous from eyes with tumours and from normal patients. In vitreous samples from eyes containing melanomas a range of S-100 protein content from less than 10 $\mathrm{ng} / \mathrm{ml}$ to $11000 \mathrm{ng} / \mathrm{ml}$ was encountered. Vitreous fluids containing abundant $(>1000 \mathrm{ng} / \mathrm{ml}) \mathrm{S}-100$ protein were from patients with moderate sized to large tumours $\left(262-1512 \mathrm{~mm}^{3}\right)$ that were usually lightly pigmented (4 of 5) and choroidal in origin. Low S-100 protein content was found in vitreous from patients with both large and small tumours. Three of 8 were substantially pigmented. Most were of mixed cellularity ( 5 of 8$)$. Two were of iris or ciliary body origin.

Vitreous from one melanoma patient (no. 13) was obtained during vitrectomy three months after removal of the tumour. It contained little S-100 protein $(16 \mathrm{ng} / \mathrm{nl})$. Vitreous fluids from patients with rhegmatogenous retinal detachment were found to have detectable levels of S-100 protein (mean, 533 $\mathrm{ng} / \mathrm{ml}$ ), higher than that detected in normal eyes (mean, $64 \mathrm{ng} / \mathrm{ml}$ ).

Table 5 lists S-100 protein levels in aqueous humour obtained from eyes with melanoma and from patients without tumours. All contained detectable but very low levels of protein.

\section{Discussion}

S-100 protein, first extracted from bovine brain by Moore $^{s}$ and named for its solubility in saturated ammonium sulphate at neutral $\mathrm{pH}$, is a thermolabile, acidic, calcium-binding protein with a molecular weight of 21000 daltons. ${ }^{(-9}$ The molecule is a dimer composed of two very similar subunits a and $b$, each with a molecular weight of 10500 . Three dimeric forms exist: $\mathrm{S}-100^{\mathrm{a} o}(\mathrm{aa}), \mathrm{S}-100^{\mathrm{a}}(\mathrm{ab})$, and $\mathrm{S}-100^{\mathrm{b}}$ (bb). ${ }^{8}$ Amino acid sequencing has shown similarities 
Table 4 S-100 protein content of vitreous

\begin{tabular}{|c|c|c|c|c|c|c|}
\hline \multirow[t]{2}{*}{ Patient } & \multirow[t]{2}{*}{ Disorder } & \multirow{2}{*}{$\begin{array}{l}\text { S-100 protein } \\
(\mathrm{ng} / \mathrm{ml})\end{array}$} & \multicolumn{4}{|c|}{ Ocular melanoma tumour characteristics } \\
\hline & & & Site & Volume $\left(\mathrm{mm}^{3}\right)$ & Cytology & Pigmentation \\
\hline 1 & Melanoma & 11000 & Choroid & 450 & Spindle & Light \\
\hline 2 & Melanoma & 3400 & Choroid & 1400 & Mixed & Heavy \\
\hline 3 & Melanoma & 8500 & Choroid & 1512 & Spindle & Light \\
\hline 4 & Melanoma & 2000 & Choroid & 262 & Spindle & Light \\
\hline 5 & Melanoma & 1024 & Choroid & 720 & Mixed & Light \\
\hline 6 & Melanoma & 240 & Iris & 144 & Spindle & Light \\
\hline 7 & Melanoma & 160 & Choroid & 720 & Mixed & Light \\
\hline 8 & Melanoma & $<10$ & Choroid & 840 & Mixed & Moderate \\
\hline 9 & Melanoma & $<10$ & Iris/CB* & 60 & Mixed & Light \\
\hline 10 & Melanoma & 40 & Choroid & 1515 & Mixed & Moderate \\
\hline 11 & Melanoma & 480 & Choroid & 840 & Spindle & Light \\
\hline 12 & Melanoma & $<10$ & Choroid & 1870 & Mixed & Heavy \\
\hline $13+$ & Melanoma & 16 & Choroid & 1372 & Spindle & Light \\
\hline 14 & RD $\ddagger$ & 500 & & & & \\
\hline 15 & RD & 600 & & & & \\
\hline 16 & RD & 500 & & & & \\
\hline 17 & Normal & 90 & & & & \\
\hline 18 & Normal & 80 & & & & \\
\hline 19 & Normal & 60 & & & & \\
\hline 20 & Normal & 30 & & & & \\
\hline 21 & Normal & $<2$ & & & & \\
\hline 22 & Normal & 120 & & & & \\
\hline
\end{tabular}

${ }^{*} \mathrm{CB}=$ ciliary body.

†Specimen obtained at vitrectomy three months after local removal of tumour.

$\ddagger R D=$ retinal detachment.

SI conversion: $\mathrm{ng} / \mathrm{ml}=\mu \mathrm{g} / \mathrm{l}$.

between S-100 protein and other calcium-binding proteins such as calmodulin, troponin-C, and parvalbumin. ${ }^{8}$ Sequencing also reveals a close similarity of S-100 protein in many different species, indicating a striking conservation of S-100 protein during evolution. ${ }^{9}$ It is present in the cytoplasm and nucleoplasm of cells and may also be present in a membranebound form.

Following its identification in brain, S-100 protein was identified in glial cells, ${ }^{10}$ Schwann cells and satellite cells, ${ }^{11}$ melanocytes, ${ }^{12}$ and cultured melanocyte-derived cells, ${ }^{13}$ satellite cells of the adenohypophysis,$^{14}$ satellite cells of the adrenal medulla,${ }^{15}$ sustentacular cells of the carotid body, ${ }^{16}$

Table 5 S-100 protein content of aqueous humour

\begin{tabular}{llc}
\hline Patient & Disorder & S-100 protein $(\mathrm{ng} / \mathrm{ml})$ \\
\hline 1 & Melanoma & 10 \\
2 & Melanoma & 10 \\
3 & Melanoma & 30 \\
4 & Melanoma & 10 \\
5 & Melanoma & 10 \\
6 & Melanoma & 10 \\
7 & Normal & 120 \\
8 & Normal & 80 \\
9 & Normal & 80 \\
\hline
\end{tabular}

SI conversion: $\mathrm{ng} / \mathrm{ml}=\mu \mathrm{g} / \mathrm{l}$. and interstitial cells of the pineal gland. ${ }^{17}$ The fact that these cell types are all either neural or neural crest derivatives led to the hypothesis that S-100 protein might be a marker for cells of neural crest origin. It is now clear, however, that S-100 protein is also present on cells not of neural crest origin, including chondrocytes, ${ }^{18}$ adipocytes,${ }^{19}$ myoepithelial cells, interdigitating cells of lymphoid tissue, Langerhans cells in skin,$^{20}$ and T lymphocytes.$^{21}$ It is possible that the presence of S-100 protein indicates a common metabolic function.

S-100 protein has been identified in Müller cells and the optic and ciliary nerves of the eye. ${ }^{22}$ It is expressed in the majority of primary ocular melanomas ${ }^{43}$ and is presumably also present, though at low concentrations, in uveal melanocytes. Within the eye potential sources of S-100 protein are therefore limited.

Data obtained from our tumour extraction studies confirm immunohistological studies that demonstrated substantial amounts of S-100 protein in many ocular melanomas. The quantities detected are comparable with those from a cutaneous melanoma and from an ocular glioma (a tumour previously reported to contain S-100 protein), but substantially less than those extracted from most melanoma cell culture lines. It is likely that the quantities obtained from minced tumour extracts are an underestimate, 
because mechanical disaggregation is a relatively inefficient means of protein extraction. The high yield of S-100 protein from tissue cultures also may reflect synchronisation of the cell cycle. It is known from previous studies that $\mathrm{S}-100$ protein expression is cell cycle stage-dependent, ${ }^{24}$ and accumulation of cells maximally expressing S-100 protein at culture confluence is possible. By contrast, tumours in vivo are essentially asynchronous.

Our data support the negative correlation between expression of S-100 protein and melanin, suggested previously on the basis of immunohistology. ${ }^{10}$ With immunoperoxidase techniques it is possible that the negative correlation between melanin and S-100 protein might be due to obscuring or quenching of the aminoethylcarbazole developer reaction product, thereby concealing the presence of $\mathrm{S}-100$ protein from visual observation. S-100 protein quantities in tumour extracts, culture extracts, subretinal fluids, and vitreous assessed by radioimmunoassay, however, consistently demonstrated low quantities of S-100 protein in heavily pigmented tumours. These findings strongly support the existence of a negative correlation between melanin production and S-100 protein expression. The biological basis of this negative correlation is unknown.

The quantities of S-100 protein detected in the samples of subretinal fluid varied widely but reached very high levels in some specimens. Subretinal fluid forms in a closed space. Accumulation of tumour derived material, in the absence of a rapid turnover of fluid, may explain why S-100 protein levels observed in subretinal fluids were often higher than those observed in tumour extracts. Very high levels of S-100 protein in subretinal fluid were associated mainly with hypomelanotic tumours. Subretinal fluids from eyes without tumours have not yet been examined. It is possible that such fluids would contain detectable S- 100 protein derived from melanocytes or Müller cells. It is unlikely, however, that the amount of S-100 protein would reach the very high levels sometimes seen in subretinal fluid from eyes with melanoma.

The quantities of $\mathrm{S}-100$ protein detected in vitreous were not as high as those seen in subretinal fluids, perhaps because of dilution factors due to a larger pool volume and more rapid movement of solutes out of this compartment. The highest levels were associated with moderate to large, posterior, lightly pigmented tumours. Vitreous fluids from patients with tractional retinal detachments had S-100 protein levels above normal. Although well below the level encountered in some melanoma patients, there was more S-100 protein in the vitreous fluids from the three patients with tractional retinal detachment than in vitreous from many tumour patients. It is possible that the protein was released from Müller cells or melanocytes. Aqueous fluids from melanoma patients contained little S- 100 protein, as did normal aqueous fluids.

This study demonstrates that low molecular weight tumour-associated molecules can be detected in ocular fluids in nanogram quantities by a readily applicable radioimmunoassay. Secretion of S-100 protein by cells in vitro has not been reported. It is possible that it is released by necrotic melanoma cells. Although the data provide an interesting insight into the relationship of ocular melanoma and the fluids of the eye, the fact that not all ocular melanomas express S-100 protein at a high level and the fact that this molecule does not consistently accumulate at increased concentration in ocular fluids limit the usefulness of S-100 protein quantification in ocular fluids as a diagnostic tool. It is likely, however, that other melanoma-derived molecules, such as those bearing the epitopes detected by several melanoma-directed monoclonal antibodies ${ }^{2-5}$ and melanoma-associated, ganglioside-directed monoclonal antibodies, ${ }^{26}$ could be identified by this technique. These molecules are likely to be more universally expressed by ocular melanoma cells than S-100 protein, and their expression is less likely to be related to the extent of melanogenesis in a given tumour. The detection of such melanoma-associated molecules in ocular fluids might serve as an aid to the diagnosis of intraocular melanomas.

\section{References}

1 Davidorf FH, Letson AD, Weiss ET, Levine E. Incidence of misdiagnosed and unsuspected choroidal melanomas: a 50 year experience. Arch Ophthalmol 1983; 101: 410-2.

2 Cochran AJ, Foulds WS, Damato BE, Trope GE, Morrison L, Lee WR. Assessment of immunological techniques in the diagnosis and prognosis of ocular malignant melanoma. $\mathrm{Br} J$ Ophthalmol 1985; 69: 171-6.

3 Rahi AHS. Immunology of ocular tumors. In: Garner A, Klintworth GK, eds. Pathobiology of ocular disease. New York, Dekker, 1983: 651-88.

4 Cochran AJ, Holland GN, Wen D-R, et al. Detection of cytoplasmic $\mathrm{S}-100$ protein in primary and metatastic intraocular melanomas. Invest Ophthalmol Vis Sci 1983; 24: 1153-5.

5 Moore BW. A soluble protein characteristic of the nervous system. Biochem Biophys Res Comm 1965; 19: 739-44.

6 Moore BW. Chemistry and biology of two proteins, S-100 and 14-3-2, specific to the nervous system. Int Rev Neurobiol 1972; 15: $215-55$.

7 Isobe T, Ishioka N, Okuyama T. Structural relation of two S-100) proteins in bovine brain: subunit of S-100 protein. Eur J Biochem 1981; 115: 469-74.

8 Isobe T, Ishioka N, Kocha T, Okuyama T. Chemical structure and molecular evolution of S-100 proteins. In: Peeters $\mathrm{H}$, ed. Protides of the biological fluids. Oxford: Pergammon, 1983; 30: 21-4.

9 Zuckerman JE, Herschman HR, Levine L. Appearance of a brain-specific antigen (the $\mathrm{S}-100$ protein) during human fetal development. J Neurochem 1970; 17: 247-51. 
10 Bock E. Nervous system specific proteins. J Neurochem 1978; 30: 7-14.

11 Stefansson R, Wollmann L, Moore BW. Distribution of S-100 protein outside the central nervous system. Brain Res 1982; 234: 309-17.

12 Cochran AJ, Wen D-R. S-100 protein as a marker for melanocytic and other tumors. Pathology 1985; 17: 340-5.

13 Gaynor R, Irie R, Morton DL, Herschman HR. S-100 protein in cultured human malignant melanomas. Nature 1980; 286: 400-1.

14 Nakajima T, Yamaguchi H, Takahashi K. S-100 protein in folliculostellate cells of the rat pituitary anterior lobe. Brain Res 1980; 191: 523-31.

15 Cocchia D, Michetti F. S-100 antigen in satellite cells of the adrenal medulla and the superior cervical ganglion of the rat. Cell Tissue Res 1981; 215: 103-12.

16 Kondo H, Iwanaga T, Nakajima T. Immunocytochemical study on the localization of neuron-specific enolase and S-100 protein in the carotid body of rats. Cell Tissue Res 1982; 227: 291-5.

17 Moller M, Ingild A, Bock E. Immunohistochemical demonstration of S-100 protein and GFA protein in interstitial cells of rat pineal gland. Brain Res 1978; 140: 1-13.

18 Stefansson K, Wolman RL, Moore BW, Arnason BEW. S-100 protein in human chondrocytes. Nature 1982; 295: 63-4.
19 Michetti F, Dell'Anna E, Tiberio G, Cocchia D. Immunochemical and immunocytochemical study of S-100 protein in rat adipocytes. Brain Res 1983; 262: 352-6.

20 Nakajima R, Watanabe S, Sato Y, Shimosato Y, Motoi M, Lennert K. S-100 protein in Langerhans cells, interdigitating reticulum cells and histiocytosis X cells. Gann 1982; 73: 429-32.

21 Kanamori M, Endo T, Shirakawa S, Sakurai M, Hidaka H. S-100 protein in human $\mathrm{T}$ lymphocytes. Biochem Biophys Res Commun 1982; 108: 1447-53.

22 Terenghi G, Cocchia D, Michett F, et al. Localization of S-100 protein in Müller cells of the retina: 1 . Light microscopical immunocytochemistry. Invest Ophthalmol Vis Sci 1983; 24: 976-80.

23 Nakajima T, Watanabe S, Sato Y, Kameya T, Shimosato Y. Immunohistochemical demonstration of S-100 protein in human malignant melanoma and pigmented nevi. Gann 1981: 72: 335-6.

24 Fan K. S-100 protein synthesis in cultured glioma cell is G-1 phase of cell cycle dependent. Brain Res 1982; 237: 498-503.

25 Burk MW. Monoclonal hybridoma antibodies in human melanoma. Current status. Int Arch Surg Oncol 1984; 7: 241-51.

26 Irie RF, Tsuchida T, Morton DL. Heterogeneity of gangliosides in human melanoma. Proc Am Assoc Cancer Res 1985; 26: 320.

Accepted for publication 20 August 1987.

\section{Correspondence}

\section{Postmeasles blindness}

SIR, The title 'Postmeasles blindness' of an editorial in your journal ${ }^{1}$ attracted my attention recently after I had read with absorbed interest the painstaking research on this subject reported by Foster and Sommer from Tanzania in the same issue. ${ }^{2}$ This paper goes a long way towards resolving the problem of the nature and relative importance of the interacting factors such as vitamin A deficiency, measles, and herpes simplex infection in causing all too frequently corneal ulceration in young African children.

Imagine my astonishment when I discovered that this paper was not even mentioned in the editorial! The reason for having an editorial at all appears to have been the very slight work of Kogbe and Liotet ${ }^{3}$ on tear changes in measles. The authors of the editorial quote only three reports on measles that are by no means typical of results on the subject reported from Africa in recent years. Without quoting any supporting evidence they come to the erroneous conclusions that 'there did not appear to be any correlation between the extent and severity of measles keratitis and nutritional status' and 'suggested that genetic factors contribute to the development of postmeasles blindness.'

Department of Medicine,

DONALD S MCLAREN

Royal Infirmary,

Edinburgh EH3 9YW

\section{References}

1 Monnickendam MA, Darougar S. Postmeasles blindness (Editorial). Br J Ophthalmol 1987; 71: 325.

2 Foster A, Sommer A. Corneal ulceration, measles, and childhood blindness. Br J Ophthalmol 1987; 71: 331-43.

3 Kogbe $\mathrm{O}$, Liotet $\mathrm{S}$. Tear electrophoretic changes in Nigerian children after measles. Br J Ophthalmol 1987; 71: 326-30.

${ }_{*}^{* *}$ I have to reject Dr McLaren's criticism of the editorial aspect of this matter. I commissioned an editorial from Dr Monnickendam and Professor Darougar on the paper by Kogbe and Liotet. They were not shown the paper by Foster and Sommer and therefore clearly, were unable to comment on it. The decision to produce an editorial on a particular paper is something I reserve the right to choose for myself as Editor. Editorials are not chosen to reward specially meritorious papers, and I agree that the paper by Foster and Sommer is absolutely excellent. That is why I published it. But editorials are intended to bring to the readers' attention some new or unusual feature which I personally regard as novel or intriguing or otherwise worthy of special comment. - R J H SMITH.

SIR, In response to Dr McLaren's criticism of our editorial we would like to make the following points.

(1) We agree with Dr McLaren that the paper by Drs Foster and Sommer about the causes of childhood blindness in Tanzania ${ }^{2}$ is very interesting. We did not refer to it in our editorial because we were not aware of it. 